\begin{abstract}
Iranica
Abstracta Iranica Revue bibliographique pour le domaine irano-aryen

Volume 40-41 | 2019

Comptes rendus des publications de 2017-2018
\end{abstract}

\title{
Moya Carey. Persian Art: Collecting the Arts of Iran for the V\&A
}

\section{Yuka Kadoi}

\section{(2) OpenEdition \\ 1 Journals}

\section{Electronic version}

URL: http://journals.openedition.org/abstractairanica/47914

DOI: 10.4000/abstractairanica.47914

ISBN: 1961-960X

ISSN: 1961-960X

\section{Publisher:}

CNRS (UMR 7528 Mondes iraniens et indiens), Éditions de l'IFRI

\section{Electronic reference}

Yuka Kadoi, "Moya Carey. Persian Art: Collecting the Arts of Iran for the V\&A", Abstracta Iranica [Online] Volume 40-41 | 2019, document 3, Online since 15 July 2019, connection on 16 April 2021. URL: http:// journals.openedition.org/abstractairanica/47914 ; DOI: https://doi.org/10.4000/abstractairanica. 47914

This text was automatically generated on 16 April 2021

Tous droits réservés 


\title{
Moya Carey. Persian Art: Collecting the Arts of Iran for the V\&A
}

\author{
Yuka Kadoi
}

\section{REFERENCES}

Moya Carey. Persian Art: Collecting the Arts of Iran for the V\&A. London: Victoria and Albert Museum, 2017, 272 p., over 200 ill.; ISBN: 9781851779338

1 The Victoria and Albert Museum in London (V\&A) is renowned for its extensive collection of Persian art. Covering almost all media of the arts from a wide chronological and geographical spectrum, the V\&A collection of Persian art took shape during the late nineteenth century, when Robert Murdoch Smith (1835-1900), Director of the Persian Telegraph Company in Tehran, undertook an unusual task to act as an agent of the Department of Science and Art for acquiring artefacts. He was active on this special mission during the period from 1873 until 1885, when he was appointed Director of the Edinburgh Museum of Science and Art. Although his collecting activities have been featured in several publications in the past, Persian Art: Collecting the Arts of Iran for the V\&A is the first comprehensive study to provide an insightful picture not only to the legacy of Robert Murdoch Smith but also to diplomatic and cultural relations between Victorian Britain and Qajar Iran. The book is divided into four case studies: 1) Master Builders: Owen Jones, Caspar Purdon Clarke and the Mirza Akbar Drawings; 2) Diplomats and Dealers: The Approach to Persian Art in 1876; 3) Modern Manufacturers and Grand Designs: The Values of Visual Historicism; and 4) From Principally Modern to Singular Perfection: The Consumer Cult of the Persian Carpet. With the focus on the roles of architects, diplomats, dealers, collectors and craftsmen, each chapter demonstrates how these players got involved in the formation of visual traditions in modern Iran. One of the highlights in this book is to bring out many, unpublished archival materials, along with the historiographical reassessment of 19thcentury examples, both well-known and relatively unknown, from the V\&A collection of Persian art. This book should be consulted in parallel with the growing number of 
publications on the art of the Qajar dynasty (1779-1924) that appeared in recent years, such as Technologies of the Image: Art in 19th-Century Iran (2017) and L'empire des roses: Chefs d'oeuvres de l'art persan du XIX siècle (2018).

\section{AUTHORS}

\section{YUKA KADOI}

University of Vienna 